\title{
Impact of marine protected areas on economical important coral reef fish communities: An evaluation of the biological monitoring of coral reef fish in Anambas Islands, Indonesia
}

\author{
RISANDI DWIRAMA PUTRA ${ }^{1}$, RIKOH MANOGAR SIRINGIRINGO ${ }^{2}$, ANI SURYANTI ${ }^{3,4, \bullet}$, \\ NI WAYAN PURNAMA SARI ${ }^{2}$, MUIN SINAGA ${ }^{5}$, NUNING VITA HIDAYATI ${ }^{6}$, FRENSLY DAMIANUS HUKOM ${ }^{2}$, \\ MUHAMMAD ABRAR ${ }^{2}$, PETRUS CHRISTIANUS MAKATIPU ${ }^{2}$, RIDHO SIANTURI ${ }^{2}$, YUWANDA ILHAM $^{7}$ \\ ${ }^{1}$ Department of Shipbuilding Engineering, Faculty of Engineering, Universitas Maritim Raja Ali Haji. Jl. Politeknik Senggarang, Tanjungpinang 29100, \\ Kepulauan Riau, Indonesia \\ ${ }^{2}$ Research Centre for Oceanography, Indonesia Institutes of Sciences. Jl. Pasir Putih I, Ancol, Pademangan, North Jakarta 14430, Jakarta, Indonesia \\ ${ }^{3}$ Department of Environmental Science, Faculty of Marine Science and Fisheries, Universitas Maritim Raja Ali Haji. Jl. Politeknik Senggarang, \\ Tanjungpinang 29100, Riau, Indonesia. Tel./fax.: +62-771-4500091, `email: yanti.ajb@umrah.ac.id \\ ${ }^{4}$ Department of Social Economy Fisheries, Faculty of Marine Science and Fisheries, Universitas Maritim Raja Ali Haji. Jl. Politeknik Senggarang, \\ Tanjungpinang 29100, Kepulauan Riau, Indonesia \\ ${ }_{5}^{5}$ Department of Marine and Fisheries, Bintan District. Bintan Buyu, Teluk Bintan, Bintan 29133, Kepulauan Riau, Indonesia \\ ${ }^{6}$ Faculty of Fisheries and Marine Science, Universitas Jenderal Soedirman. Jl. Dr. Soeparno, Purwokerto Utara, Banyumas 53122, Central Java, Indonesia \\ ${ }^{7}$ LOKA for the National Marine Protected Areas (LKKPN), Ministry of Maritime Affairs and Fisheries. J1. Budi Utomo 1, Tenayan, Payung Sekaki, \\ Pekanbaru 28156, Riau, Indonesia
}

Manuscript received: 5 April 2021. Revision accepted: 13 September 2021.

\begin{abstract}
Putra RD, Siringiringo RM, Suryanti A, Sari NWP, Sinaga M, Hidayati NV, Hukom FD, Abrar M, Makatipu PC, Sianturi R, Ilham Y. 2021. Impact of marine protected areas on economical important coral reef fish communities: An evaluation of the biological monitoring of coral reef fish in Anambas Islands, Indonesia. Biodiversitas 22: 4169-4181. The use of Marine Protected Areas (MPAs) is the core strategy to reduce the impact of the anthropogenic stressor on marine fisheries, especially in reducing the overexploitation of fisheries resources and destructive fishing in which this plays a significant role in the conservation of marine biodiversity and populations. We conducted a study over 4 years to evaluate and assess the impact of MPAs on economically important reef fish in the Anambas Islands. We compared density, size, biomass, and diversity indices from the seven families of coral reef fish (Acanthuridae, Haemulidae, Lethrinidae, Lutjanidae, Scaridae, Siganidae, and Serranidae) using Underwater Visual Census (UVC) with a total of 12 MPAs stations (70-m transect). Multivariate analysis of variance (MANOVA) was used to evaluate and assess reserve protection on the coral reef fish, and several ecological indices were used to compare the potential change of economically coral reef fish diversity. We also measured the rate of change in coral cover to identify the effectiveness of the MPAs. After 4 years of studies, our result showed that there was an increase of economical reefs. Fish diversity, density, and biomass increased by $244 \%, 257 \%$, and $179 \%$ respectively. There was no significant difference in the rate of coral cover change among MPAs stations. Economical coral reef fish in Anambas Islands were restored in marine reserve overtimes after fisheries restriction protection, but this does not change the rate of coral cover through time. In addition, the government managed and increased community awareness that significantly influenced decreasing destructive fishing practices and overexploited reef fish species in Anambas Islands but no change in coral cover. The MPAs environmental condition and natural disturbance, including thermal stress and high sedimentation, play a key role in coral cover recovery besides fisheries restriction in the MPAs area.
\end{abstract}

Keywords: Coral, density, diversity, monitoring, MPAs

\section{INTRODUCTION}

The pillars of conservation area management, namely protection, preservation, and sustainable management, are decisive factors in coral reef management. Management of protected conservation areas, preservation, and sustainable management are decisive factors in coral reef management. The establishment of marine protected areas (MPAs) around the world is the response to the recognition of the requirement for conservation of the sustainability of coral reef ecosystems (Green et al. 2011). The establishment of an MPA is one of the most appropriate initiatives for implementing coral reef conservation and sustainable fisheries management (Muallil et al. 2015). MPAs are an appropriate mechanism to protect coral reef ecosystems, manage marine fisheries, and play an important role in protecting marine biodiversity (Green et al. 2011). As coral health can be assessed by the number of functional fish, fishing pressure is estimated by summing fish counts with a measure of Algal control provided by a count of multiple herbivory fish species (Giyanto et al. 2017).

The number of MPAs was increasing rapidly throughout the world (Edgar et al. 2014), including Indonesia. Indonesia aimed to support the target of achieving 20 million $\mathrm{Ha}$ of Protected Area by 2020, in accordance with the Biodiversity Conference, which states that the Marine Protected Area (MPA) target is $10 \%$ of the world's waters. Therefore, the Indonesian government has 
established a network pattern for conservation areas. The implementation of regulations has been regulated in Article 19 of the Republic of Indonesia Government Regulation No. 60 of 2007 concerning Conservation of Fish Resources, which states that in the management of marine conservation areas, a network of marine conservation areas can be formed at local, national, regional and global levels.

The existence of a conservation area also determines the size of the fish and their population density (Fidler et al. 2017). Large-sized fish outside the MPA has a very low density (Muallil et al. 2015). The positive impact of MPAs has long been studied since it was established in the early 70 s and has become a common mechanism for fisheries management and biodiversity protection to increase fish communities (Corrales et al. 2015).

MPAs improve the important function of the coral reef ecosystem by increasing the species richness of wandering herbivores both directly and indirectly. Particularly MPAs increase local herbivore richness (diversity) and biomass (Topor et al. 2019). This is an indication that without MPA management, there is a high risk of destructive fishing activities. MPAs essentially plays an important role in fisheries. The declaration of MPAs Anambas Island officially based on the Ministerial Decree of the Ministry of Marine Affairs and Fisheries (MMAF) Indonesia and designation as Marine Recreational Park (MRP) (Pregiwati et al. 2015). Reef Health Monitoring conservation, and long-term protection, and proper management is required to increase fish populations in terms of fish diversity (Corrales et al. 2015). Researchers tried to compare density, size, biomass, and diversity indexes of seven coral reef fish families to evaluate and assess the impact of Marine Protected Area (MPA) reserves on economically important reef fish in the Anambas Islands, Indonesia.

\section{MATERIALS AND METHODS}

\section{Study area}

Anambas Islands (Riau Islands Province, Indonesia) was one of the nominated total thirteen most important Marine Protected Areas (MPAs) in the coral triangle Marine Protected Area System (CTMPAS) based on Coral Triangle Initiative (CTI) news in 2014. (RHM) conducted by Research of Oceanography, Indonesia Institute of Science found that MPAs of Anambas Island had a coral cover with an area of 1,165.25 ha (Siringoringo et al. 2015). Anambas is a large coastal coral reef area with $6,260 \mathrm{Ha}$ of coral cover near the North Natuna Sea or South Chinese Sea (Vo et al. 2013). Eleven small islands in twelve site locations in Anambas Marine Protected Area (MPA) were monitored in 2015 and 2019 (Figure 1) to quantify benthic community structure and reef fish composition (species richness, density, and biomass) and the coordinate location of each island and site were presented (Table 1). The coral reef sites were selected in close distance to the shore, and some reef sites had different reef structures, including fringing reef, patch reef, long reef flat, and reef slope. The reef was found more than 16 meters and transect of studies laying in 5 to 8 meters depending on tide and reef structure.

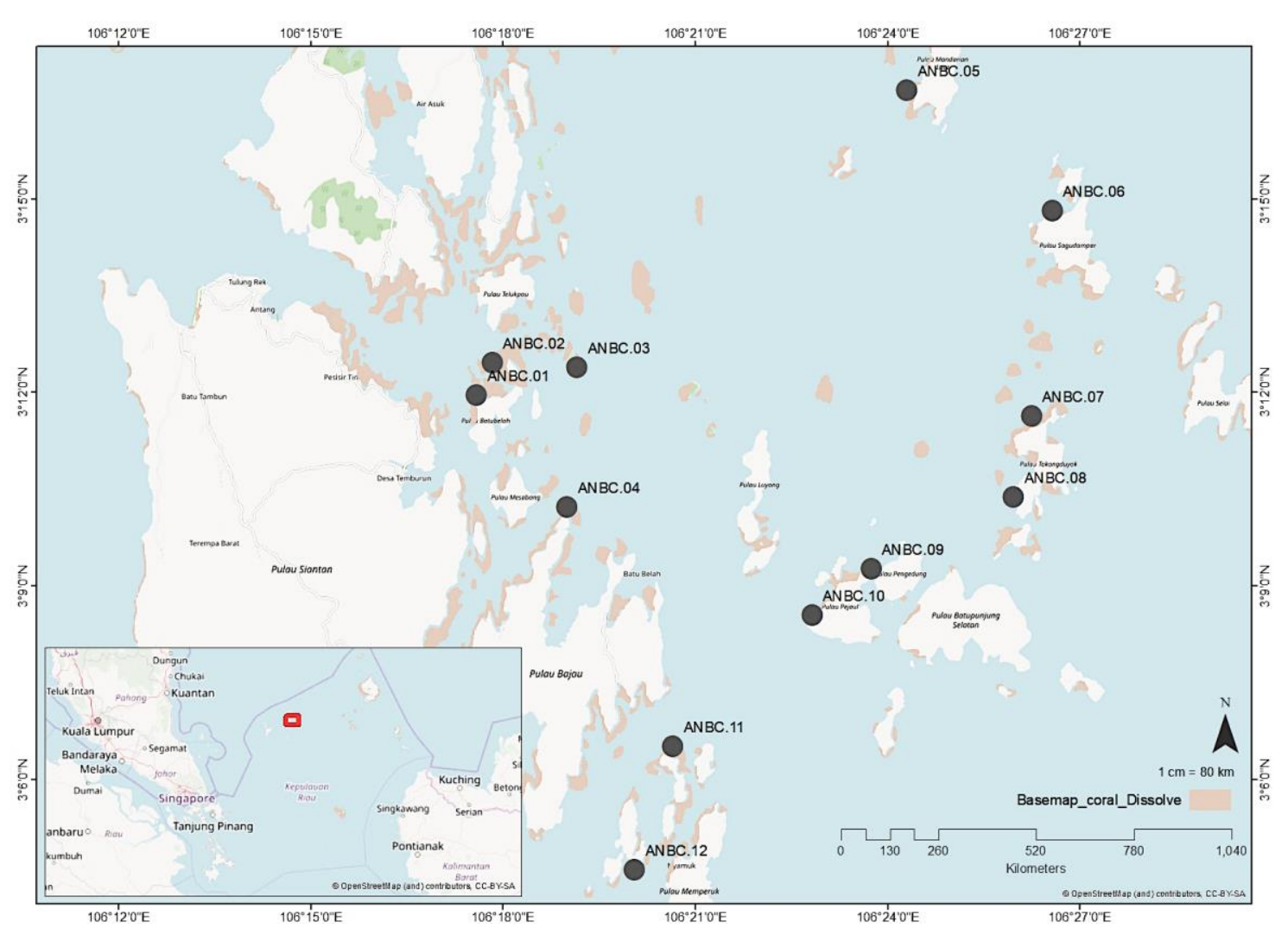

Figure 1. Map of Anambas Islands (Riau Islands Province, Indonesia) of the twelve MPAs as study sites 
Table 1. Geographic coordinates, location and reef sites description of twelve MPAs sites location

\begin{tabular}{ccclccc}
\hline Sites & Latitude & Longitude & \multicolumn{1}{c}{ Location } & $\begin{array}{c}\text { Transect } \\
\text { (depth) }\end{array}$ & Visibility & $\begin{array}{c}\text { Transect location } \\
\text { (Slope) }\end{array}$ \\
\hline ANBC.01 & 3.199285 & 106.2932 & Batu Belah Island & 6 meters & \pm 10 meters & 35 \\
ANBC.02 & 3.207633 & 106.2973 & Pauh Island & 6 meters & \pm 8 meters & 40 \\
ANBC.03 & 3.206419 & 106.3193 & Reef Tumewa Island & 5 meters & \pm 8 meters & 40 \\
ANBC.04 & 3.170275 & 106.3168 & North Bajau Island & 7.5 meters & \pm 20 meters & 65 \\
ANBC.05 & 3.278065 & 106.4052 & Mandarian Island & 5 meters & \pm 15 meters & 40 \\
ANBC.06 & 3.246888 & 106.4430 & Samak Island & 6 meters & \pm 15 meters & 30 \\
ANBC.07 & 3.193969 & 106.4376 & North Tokongduyok Island & 7 meters & \pm 20 meters & 45 \\
ANBC.08 & 3.172936 & 106.4329 & South Tokongduyok Island & 6.5 meters & \pm 20 meters & 45 \\
ANBC.09 & 3.154493 & 106.3958 & Pengedung Island & 6 meters & \pm 10 meters & 40 \\
ANBC.10 & 3.142414 & 106.3805 & Pejaul Island & 6 meters & \pm 15 meters & 50 \\
ANBC.11 & 3.108592 & 106.3442 & Urukuruk Island & 7 meters & \pm 20 meters & 50 \\
ANBC.12 & 3.076569 & 106.3343 & Pemutus Island & 7 meters & \pm 20 meters & 45 \\
\hline
\end{tabular}

\section{Benthic community structure}

To estimate the percentage cover of benthic community composition in 2015 and 2019, we assessed $(58 \times 44) \mathrm{cm}^{2}$ photo-quadrat every 1 meter along 50-meter long transect line using a digital camera (Canon G12 with underwater housing) based on modification permanent photo-quadrat transect from (Hill and Wilkinson 2004). A total of 1200 photo-quadrat on 12 sites in 2015 and 2019 studies was analyzed using the software Coral Point Count with Excel Extension Software (CPCe) (Kohler and Gill 2006). Thirty randomly overlaid points were distributed in each photoquadrat to quantify the percentage cover of benthic community structure or 1500 points per transect line (totaling 36000 points in this study). The benthic community categories were identified following the standard code given by (Giyanto et al. 2014): Hard Coral (HC); Recent Dead Coral (DC); Dead Coral with Algae (DCA); Soft Coral (SC); Sponge (SP); Fleshy seaweed (FS); Other Biota (OT); Rubble (R); Sand (S); Acropora (AC); and Non-Acropora (NAC). The code and benthic community categories were automatically counted in Excel extension by CPCe software (Giyanto et al. 2014; Hadi et al. 2018).

\section{Reef fish composition}

We performed Underwater Visual Census (UVC) to estimate reef fish species composition, density, and biomass. Most research studying reef fish composition used UVC methods (Samoilys and Carlos 2000; Pet-Soede et al. 2001; Mallet et al. 2014; Corrales et al. 2015; Caldwell et al. 2016; Bacheler et al. 2017; Fidler et al. 2017; Putra et al. 2018; Wilson et al. 2018). Underwater Visual Census is a common method to estimate coral reef composition because this method provides rapid and effective cost studies (Wilson et al. 2018). Moreover, this requires minimum personnel and equipment, environmental friendly (Giyanto et al. 2014), and is suitable for the dynamic mobility of target species (Hill and Wilkinson 2004). The divers were experiences, very well-trained, and certified from National Professional Certification Agency Indonesia by knowing reef fish species, counting and estimating fish size underwater. At each MPAs we identified, counted and estimated the length of reef fish (total length or fork length) within $2.5 \times 70$ meters of belt transect (Putra et al. 2018).
The total length of reef fish species was recorded from fish with rounded and truncated caudal fins, and fork length was recorded for other reef fish species (Cox et al. 2017). The reef fish length data were used to analyze fish biomass for twelve sites in Anambas MPA area by converting individual length $(\mathrm{cm})$ to weight $(\mathrm{g})$ using allometric length-weight relationship, $\mathrm{W}=\mathrm{aTLb}$, where $\mathrm{W}$ is the weight of each individual reef fish species, TL is the length of each reef fish species (total length or fork length) that estimates from underwater visual census survey, $a$ and $b$ are coefficient-specific of reef fish from fishbase.org (Froese and Pauly 2019). If coefficient-specific a and b were not available, we used the values of congeneric species of the similar genus, morphology (Cox et al. 2017) and body types (Corrales et al. 2015). Coral reef fish for this study consisted of fish species in the different of the functional group had to influence for coral ecosystem and economical important reef fish that directly targeted by fisher for food in the Anambas Island: the first group from corallivore fish (Chaetodontidae); a second group from herbivorous fish (Acanthuridae, Scaridae, and Siganidae); and the third group from carnivorous fish (Haemulidae, Lethrinidae, Lutjanidae and Serranidae).

\section{Data analysis}

Coral reef fish in MPAs area Anambas Islands were identified to the species level following standardized procedures (Kuiter and Tonozuka 2001a; Kuiter and Tonozuka 2001b; Kuiter and Tonozuka 2001c; Allen et al. 2003; Du et al. 2016) and Fishbase.org access (Froese and Pauly 2019). For each family, we identified functional groups level and International Union for Conservation of Nature (IUCN) Red List status from iucnrelist.org. The differences in density of each reef fish species in 2015 and 2019 were assessed based on mean and standard deviation in twelve sites (Table 2). The Species rank of reef fish was visualized with $\mathrm{R}$ software version 3.6.1 with tidyverse packages from (Wickham 2017) and sorted by high density with different family groups for both 2015 and 2019 data. We compared and analysed the changing condition of mean from influence of benthic community structure (Hard Coral and Dead Coral Algae) with a density of reef fish (herbivorous and coralivorous) between the twelve MPAs site in 2015 
and 2019. The evaluation of the biological monitoring of coral reef fish in Anambas Islands from the impact of controlling MPAs area was visualized in changing of reef fish composition structure (species richness, density, and biomass) of each family and analyzed by Multivariate Analysis of Variance (MANOVA). To analyze the impact of benthic community structure on reef fish composition at each MPA site in 2015 and 2019, we conducted a correspondence analysis (CA analysis) based on modification variables from Planes et al. (2012). Coral reef fish diversity in 2015 and 2019 was measured with selection the most popular diversity index, including Shannon's diversity index (H'), Pielou's evenness index (J), and Simpson's dominance index $(\mathrm{S})$ at each sampling site.

\section{RESULTS AND DISCUSSION}

A total 66 economical important reef fish (and indicator fish: Chaetodontidae) was recorded, representing 3 functional group (corallivore, herbivore, carnivore) and 7 families (Chaetodontidae, Scaridae, Siganidae, Haemulidae, Lethrinidae, Lutjanidae, Serranidae) along with pre-controlling MPAs (2015) and intensively controlling MPAs area (2019). The dominance of reef fish species from herbivore fish was Scaridae with the highest species number (20 species) was followed by Chaetodontidae (14 species), Serranidae (10 species), Lutjanidae (8 species), Siganidae (7 species), Lethrinidae (4 species) and Haemulidae (3 species). Five of the recorded reef fish species in MPAs survey sites of the Anambas Islands were included in the IUCN Red List wherein one species was considered Vulnerable (Bolbometopon muricatum) was $1.17 \pm 2.37$ individuals/ $350 \mathrm{~m}^{2}$ in 2015 and increased to $1.33 \pm 2.81$ individuals $/ 350 \mathrm{~m}^{2}$ in 2019 . Four other species were considered as Near Threatened status, including Chaetodon trifascialis. That species was not found in 2015 in contrast found with $0.08 \pm 0.29$ individuals $/ 350 \mathrm{~m}^{2}$ in 2019 , Chlorurus bowersi with $2.08 \pm$ 2.64 individuals $/ 350 \mathrm{~m}^{2}$ in 2015 and then increased to 3.83 \pm 3.01 individuals $/ 350 \mathrm{~m}^{2}$, and in 2019, Plectropomus leopardus was $0.08 \pm 0.29$ individuals $/ 350 \mathrm{~m}^{2}$ in 2015 , while the species was not found in 2019 MPAs sites location. Chaetodon octofasciatus from corallivore group was the dominant species in pre-controlling MPAs in 2015 with $8.33 \pm 5.12$ individuals $/ 350 \mathrm{~m}^{2}$, and then increased to $11.75 \pm 4.67$ individuals / $350 \mathrm{~m}^{2}$ in 2019 . Herbivore group of Scarus quoyi and Scarus rivulatus were dominant species in 2019 with $7.33 \pm 7.04$ and $10.67 \pm 9.34$ individuals $/ 350 \mathrm{~m}^{2}$, respectively.

Forty-two reef fish species were recorded during the sampling period in 2015, and the number of reef fish species increased significantly to fifty-four species in 2019. There were a few additional reef fish species of each functional group reef fish in 2019, including corralivore group (Chaetodon lunula, Chaetodon lunulatus, Chaetodon Triangulum Chaetodon trifascialis, Coradion chrysozonus), herbivorous group (Cetoscarus occelatus, Scarus chameleon, Scarus flavipectoralis, Scarus forsteni, Scarus niger, Scarus prasiognathos, Scarus rivulatus, Scarus tricolor) and carnivorous group (Plectorhinchus lessonii, Lethrinus erythropterus, Lethrinus harak, Lethrinus ornatus, Lutjanus fulviflamma, Lutjanus monostigma, Lutjanus quinquelineatus, Lutjanus vitta, Diploprion bifasciatum, Plectropomus oligacanthus). In terms of species rank of density reef fish, Chaetodon octofasciatus from corralivore functional grouphad very high abundance in 2015, whereas from other functional groups to herbivorous and carnivorous reef fish in 2015, Scarus ghobban and Lutjanus carponotatus were dominance species, respectively. The condition of reef fish composition changed in 2019. There was a surprising pattern of reef fish composition in which herbivorous fish Scarus quoyi was the dominant species in Anambas Islands. Lutjanus carponotatus and Chaetodon octofasciatus were still dominance species for carnivorous and corallivore, respectively.

A monotonous trend showed the percentage benthic community structure for life coral and dead coral algae cover from 2015 to 2019 . The mean percentage of live coral cover in twelves site locations showed a decreasing percentage from $41.88 \%$ in 2015 to $40.37 \%$ in 2019 . Dead coral with algae had different trends performance from life coral, with two periods identified from 2015 to 2019, and the percentage of DCA cover was increased $2.76 \%$ from $42.33 \%$ in 2015. A general trend increase in density of a functional group of reef fish was detected from 2015 to 2019 with a less than double mean density of corallivore fish (x 1.3) while the mean density of herbivorous fish increased almost three times (x 2.6). The comparable result obtained from benthic community structure and reef fish density composition in two periods 2015 and 2019 showed a surprising result. There was a decreasing coral condition in Anambas Islands while the reef fish condition increased significantly. The result proved and supported that longterm protection and control of MPAs area increased in economical fish density but did not support the condition coral reef.

In general, the diversity, density, and biomass of the seven economically important reef fish in the Anambas Islands showed an increasing trend between periods of studies (2015 to 2019) (Figure 4). Reef fish diversity showed in the species richness presented a good indication of the succession MPAs management in the Anambas Islands. All seven economically important reef fish families monitored (Chaetodontidae, Scaridae, Siganidae, Haemulidae, Lethrinidae, Lutjanidae, and Serranidae) showed an increasing number of species richness, especially Scaridae family with the highest increasing number of species richness. A similar trend was also showed that in the density performance of reef fish, increasing fish diversity will be followed by density (Peck et al. 2021). Scaridae had the most abundant and increased density performance among the seven reef fish families, followed by Chaetodontidae, Siganidae, Lutjanidae, Serranidae, Lethrinidae, and Haemulidae. The mean biomass of each economical important reef fish also showed an increasing trend but not as significant as diversity and density. Based on the result, the mean biomass of each family of economically important reef fish inside the MPAs did not vary greatly. There were no differences in the fish biomass during fish monitoring from 2015 to 2019. 
Table 2. The change of mean density and standard error (mean \pm SE) from each species reef fish composition with the functional group and IUCN Red List Status causing the impact of controlling MPAs area in Anambas Islands, Riau Islands Province, Indonesia

\begin{tabular}{|c|c|c|c|c|c|}
\hline Species & 2015 & 2019 & Family & Functional groups & IUCN Red List status \\
\hline Aethaloperca rogaa & $0.25 \pm 0.62$ & $0.00 \pm 0.00$ & Serranidae & Carnivorous & $\mathrm{LC}$ \\
\hline Bolbometopon muricatum & $1.17 \pm 2.37$ & $1.33 \pm 2.81$ & Scaridae & Herbivorous & VU \\
\hline Cephalopholis boenak & $0.50 \pm 1.00$ & $1.00 \pm 0.74$ & Serranidae & Carnivorous & $\mathrm{LC}$ \\
\hline Cephalopholis cyanostigma & $0.08 \pm 0.29$ & $1.42 \pm 2.35$ & Serranidae & Carnivorous & $\mathrm{LC}$ \\
\hline Cephalopholis microprion & $0.25 \pm 0.87$ & $0.92 \pm 1.16$ & Serranidae & Carnivorous & $\mathrm{LC}$ \\
\hline Cephalopholis argus & $0.58 \pm 1.24$ & $0.00 \pm 0.00$ & Serranidae & Carnivorous & $\mathrm{LC}$ \\
\hline Cephalopholis leopardus & $0.08 \pm 0.29$ & $0.00 \pm 0.00$ & Serranidae & Carnivorous & $\mathrm{LC}$ \\
\hline Cetoscarus ocellatus & $0.00 \pm 0.00$ & $0.83 \pm 1.47$ & Scaridae & Herbivorous & $\mathrm{LC}$ \\
\hline Chaetodon adiergastos & $1.17 \pm 2.33$ & $0.42 \pm 0.90$ & Chaetodontidae & Coralivorous & $\mathrm{LC}$ \\
\hline Chaetodon baronessa & $1.33 \pm 1.92$ & $1.33 \pm 1.23$ & Chaetodontidae & Coralivorous & $\mathrm{LC}$ \\
\hline Chaetodon lineolatus & $0.08 \pm 0.29$ & $0.17 \pm 0.58$ & Chaetodontidae & Coralivorous & $\mathrm{LC}$ \\
\hline Chaetodon lunula & $0.00 \pm 0.00$ & $0.08 \pm 0.29$ & Chaetodontidae & Coralivorous & $\mathrm{LC}$ \\
\hline Chaetodon lunulatus & $0.00 \pm 0.00$ & $0.17 \pm 0.58$ & Chaetodontidae & Coralivorous & $\mathrm{LC}$ \\
\hline Chaetodon octofasciatus & $8.33 \pm 5.12$ & $11.75 \pm 4.67$ & Chaetodontidae & Coralivorous & $\mathrm{LC}$ \\
\hline Chaetodon speculum & $0.08 \pm 0.29$ & $0.00 \pm 0.00$ & Chaetodontidae & Coralivorous & $\mathrm{LC}$ \\
\hline Chaetodon triangulum & $0.00 \pm 0.00$ & $0.25 \pm 0.62$ & Chaetodontidae & Coralivorous & $\mathrm{LC}$ \\
\hline Chaetodon trifascialis & $0.00 \pm 0.00$ & $0.08 \pm 0.29$ & Chaetodontidae & Coralivorous & NT \\
\hline Chaetodon trifasciatus & $0.33 \pm 0.89$ & $0.33 \pm 0.78$ & Chaetodontidae & Coralivorous & $\mathrm{LC}$ \\
\hline Chelmon rostratus & $1.58 \pm 1.78$ & $1.67 \pm 1.67$ & Chaetodontidae & Coralivorous & $\mathrm{LC}$ \\
\hline Chlorurus bleekeri & $1.92 \pm 2.87$ & $6.33 \pm 3.96$ & Scaridae & Herbivorous & $\mathrm{LC}$ \\
\hline Chlorurus bowersi & $2.08 \pm 2.64$ & $3.83 \pm 3.01$ & Scaridae & Herbivorous & NT \\
\hline Chlorurus michrohinos & $0.17 \pm 0.58$ & $0.67 \pm 1.50$ & Scaridae & Herbivorous & $\mathrm{LC}$ \\
\hline Chlorurus sordidus & $0.25 \pm 0.87$ & $3.25 \pm 3.44$ & Scaridae & Herbivorous & $\mathrm{LC}$ \\
\hline Coradion chrysozonus & $0.00 \pm 0.00$ & $0.08 \pm 0.29$ & Chaetodontidae & Coralivorous & $\mathrm{LC}$ \\
\hline Diagramma pictum & $0.17 \pm 0.39$ & $0.33 \pm 0.78$ & Haemulidae & Carnivorous & $\mathrm{NE}$ \\
\hline Diploprion bifasciatum & $0.00 \pm 0.00$ & $0.42 \pm 1.44$ & Serranidae & Carnivorous & $\mathrm{LC}$ \\
\hline Heniochus singularis & $0.08 \pm 0.29$ & $0.00 \pm 0.00$ & Chaetodontidae & Coralivorous & $\mathrm{LC}$ \\
\hline Heniochus varius & $0.08 \pm 0.29$ & $0.25 \pm 0.87$ & Chaetodontidae & Coralivorous & $\mathrm{LC}$ \\
\hline Lethrinus erythropterus & $0.00 \pm 0.00$ & $1.58 \pm 2.84$ & Lehtrinidae & Carnivorous & $\mathrm{LC}$ \\
\hline Lethrinus harak & $0.00 \pm 0.00$ & $0.17 \pm 0.58$ & Lehtrinidae & Carnivorous & $\mathrm{LC}$ \\
\hline Lethrinus lentjan & $0.08 \pm 0.29$ & $0.08 \pm 0.29$ & Lehtrinidae & Carnivorous & $\mathrm{LC}$ \\
\hline Lethrinus ornatus & $0.00 \pm 0.00$ & $0.00 \pm 0.00$ & Lehtrinidae & Carnivorous & $\mathrm{LC}$ \\
\hline Lutjanus carponotatus & $2.25 \pm 2.34$ & $3.58 \pm 3.34$ & Lutjanidae & Carnivorous & $\mathrm{LC}$ \\
\hline Lutjanus decussatus & $1.00 \pm 1.21$ & $1.92 \pm 2.57$ & Lutjanidae & Carnivorous & $\mathrm{LC}$ \\
\hline Lutjanus fulviflamma & $0.00 \pm 0.00$ & $0.42 \pm 1.44$ & Lutjanidae & Carnivorous & $\mathrm{LC}$ \\
\hline Lutjanus fulvus & $0.08 \pm 0.29$ & $0.08 \pm 0.29$ & Lutjanidae & Carnivorous & $\mathrm{LC}$ \\
\hline Lutjanus monostigma & $0.00 \pm 0.00$ & $0.42 \pm 0.79$ & Lutjanidae & Carnivorous & $\mathrm{LC}$ \\
\hline Lutjanus quinquelineatus & $0.00 \pm 0.00$ & $3.50 \pm 11.51$ & Lutjanidae & Carnivorous & $\mathrm{LC}$ \\
\hline Lutjanus vitta & $0.00 \pm 0.00$ & $0.17 \pm 0.58$ & Lutjanidae & Carnivorous & $\mathrm{LC}$ \\
\hline Plectorhinchus lessonii & $0.00 \pm 0.00$ & $0.17 \pm 0.58$ & Haemulidae & Carnivorous & NE \\
\hline Plectorhinchus chaetodonoides & $0.33 \pm 0.89$ & $0.50 \pm 0.80$ & Haemulidae & Carnivorous & $\mathrm{NE}$ \\
\hline Plectropomus leopardus & $0.08 \pm 0.29$ & $0.00 \pm 0.00$ & Serranidae & Carnivorous & NT \\
\hline Plectropomus maculatus & $0.25 \pm 0.45$ & $0.33 \pm 0.49$ & Serranidae & Carnivorous & $\mathrm{LC}$ \\
\hline Plectropomus oligacanthus & $0.00 \pm 0.00$ & $0.00 \pm 0.00$ & Serranidae & Carnivorous & $\mathrm{LC}$ \\
\hline Scarus chameleon & $0.00 \pm 0.00$ & $0.25 \pm 0.62$ & Scaridae & Herbivorous & $\mathrm{LC}$ \\
\hline Scarus dimidiatus & $3.58 \pm 3.34$ & $0.83 \pm 1.47$ & Scaridae & Herbivorous & $\mathrm{LC}$ \\
\hline Scarus flavipectoralis & $0.00 \pm 0.00$ & $0.08 \pm 0.29$ & Scaridae & Herbivorous & $\mathrm{LC}$ \\
\hline Scarus forsteni & $0.00 \pm 0.00$ & $0.08 \pm 0.29$ & Scaridae & Herbivorous & $\mathrm{LC}$ \\
\hline Scarus frenatus & $0.17 \pm 0.39$ & $0.17 \pm 0.58$ & Scaridae & Herbivorous & $\mathrm{LC}$ \\
\hline Scarus ghobban & $4.42 \pm 5.26$ & $1.42 \pm 1.31$ & Scaridae & Herbivorous & $\mathrm{LC}$ \\
\hline Scarus hypselopterus & $0.33 \pm 0.78$ & $2.25 \pm 2.45$ & Scaridae & Herbivorous & NT \\
\hline Scarus niger & $0.00 \pm 0.00$ & $1.58 \pm 1.68$ & Scaridae & Herbivorous & $\mathrm{LC}$ \\
\hline Scarus oviceps & $0.08 \pm 0.29$ & $0.92 \pm 1.78$ & Scaridae & Herbivorous & $\mathrm{LC}$ \\
\hline Scarus prasiognathos & $0.00 \pm 0.00$ & $0.08 \pm 0.29$ & Scaridae & Herbivorous & $\mathrm{LC}$ \\
\hline Scarus psittacus & $0.17 \pm 0.58$ & $0.00 \pm 0.00$ & Scaridae & Herbivorous & $\mathrm{LC}$ \\
\hline Scarus quoyi & $0.92 \pm 1.24$ & $7.33 \pm 7.04$ & Scaridae & Herbivorous & $\mathrm{LC}$ \\
\hline Scarus rivulatus & $0.00 \pm 0.00$ & $10.67 \pm 9.34$ & Scaridae & Herbivorous & $\mathrm{LC}$ \\
\hline Scarus tricolor & $0.00 \pm 0.00$ & $0.08 \pm 0.29$ & Scaridae & Herbivorous & $\mathrm{LC}$ \\
\hline Siganus corralinus & $0.33 \pm 1.15$ & $0.25 \pm 0.62$ & Siganidae & Herbivorous & $\mathrm{LC}$ \\
\hline
\end{tabular}




\begin{tabular}{llllll}
\hline Siganus doliatus & $0.67 \pm 1.23$ & $0.00 \pm 0.00$ & Siganidae & Herbivorous & LC \\
Siganus guttatus & $0.00 \pm 0.00$ & $0.33 \pm 1.15$ & Siganidae & Herbivorous & LC \\
Siganus puellus & $0.50 \pm 1.24$ & $2.75 \pm 2.93$ & Siganidae & Herbivorous & LC \\
Siganus punctatus & $0.08 \pm 0.29$ & $0.00 \pm 0.00$ & Siganidae & Herbivorous & LC \\
Siganus virgatus & $1.42 \pm 1.24$ & $4.08 \pm 4.58$ & Siganidae & Herbivorous & LC \\
Siganus vulpinus & $1.75 \pm 1.36$ & $1.67 \pm 1.50$ & Siganidae & Herbivorous & LC \\
Symphoricthys spilurus & $0.08 \pm 0.29$ & $0.00 \pm 0.00$ & Lutjanidae & Carnivorous & LC \\
\hline
\end{tabular}

LC: Least Concern; NE: Not Evaluated; NT: Near Threatened; V: Vulnerable

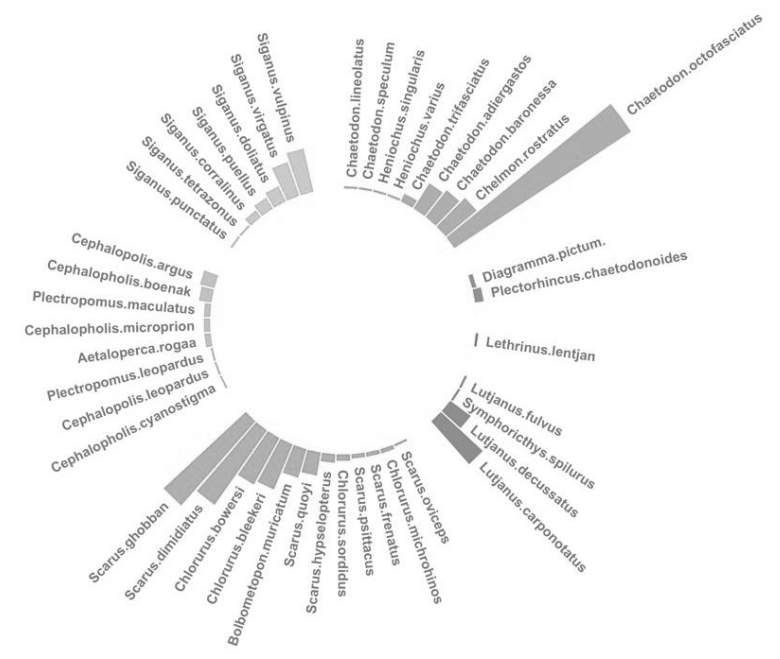

A

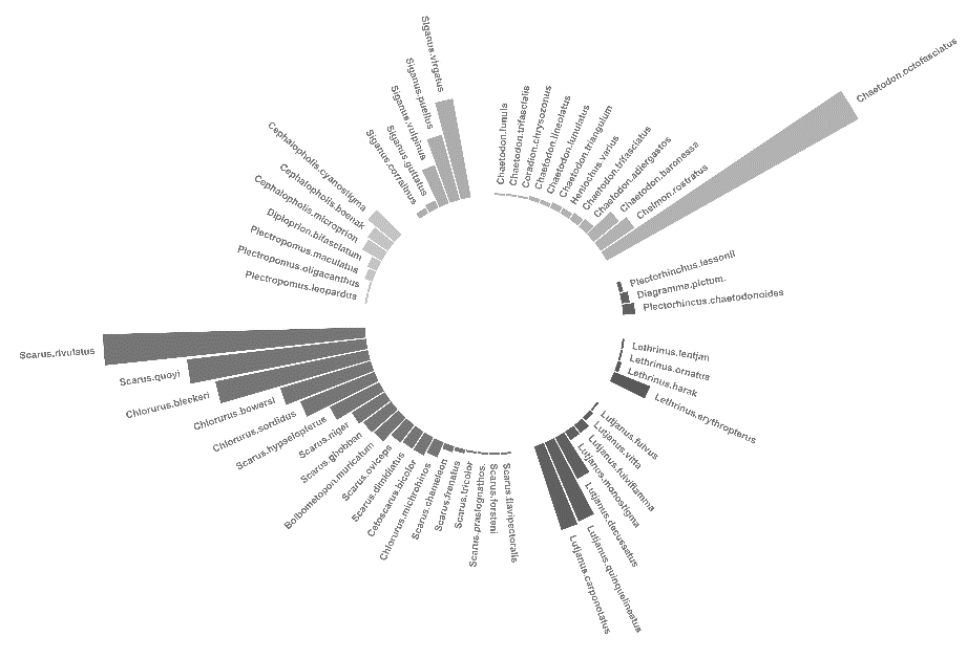

B

Figure 2. Species rank of reef fish species based on family group MPAs Anambas Islands, Riau Islands Province, Indonesia in 2015 (A) and $2019(\mathrm{~B})$
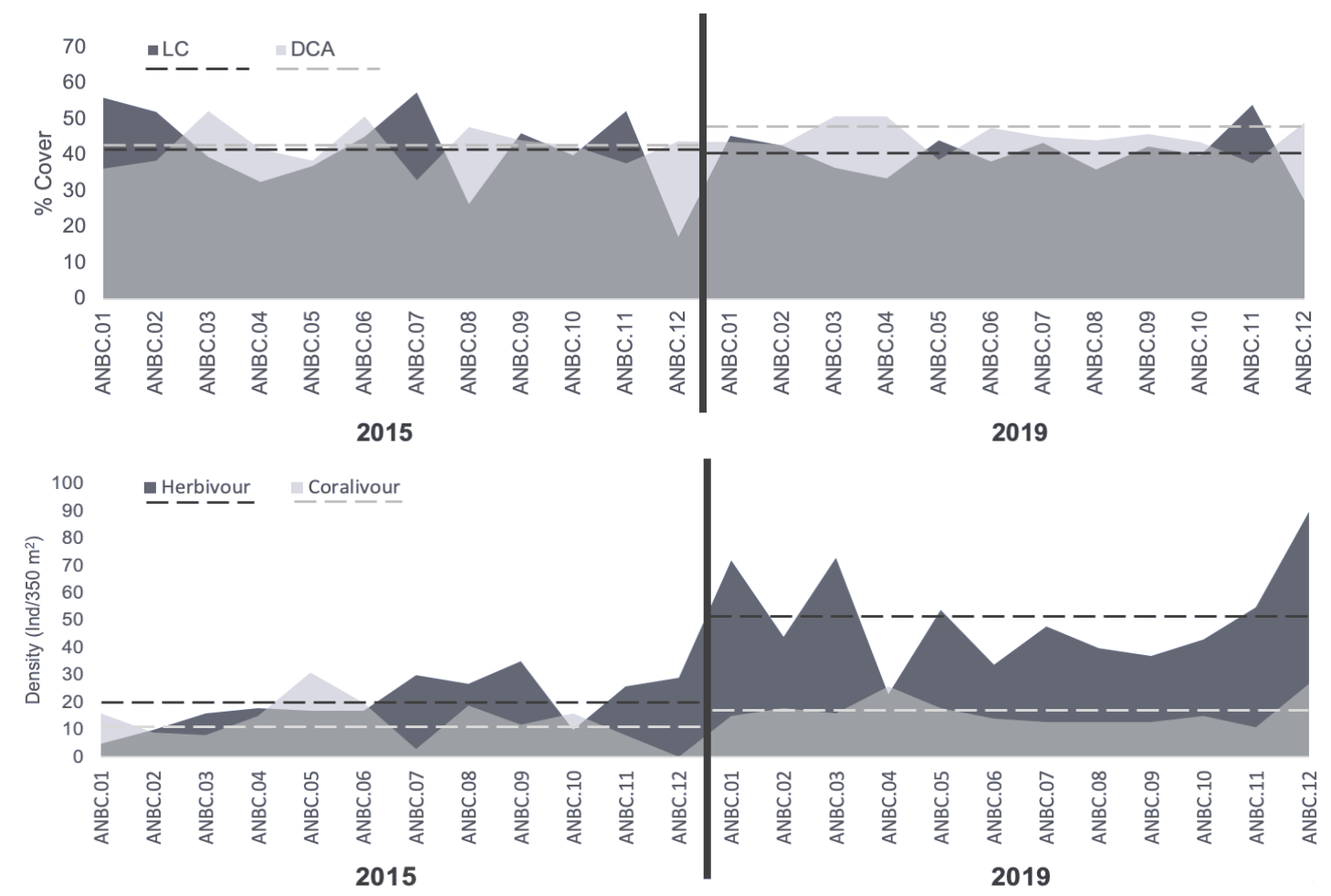

Figure 3. The percentage benthic community structure (life coral, dead coral with algae) and density of functional group reef fish (herbivorous, coralivorous) on twelve MPA site in 2015 and 2019 

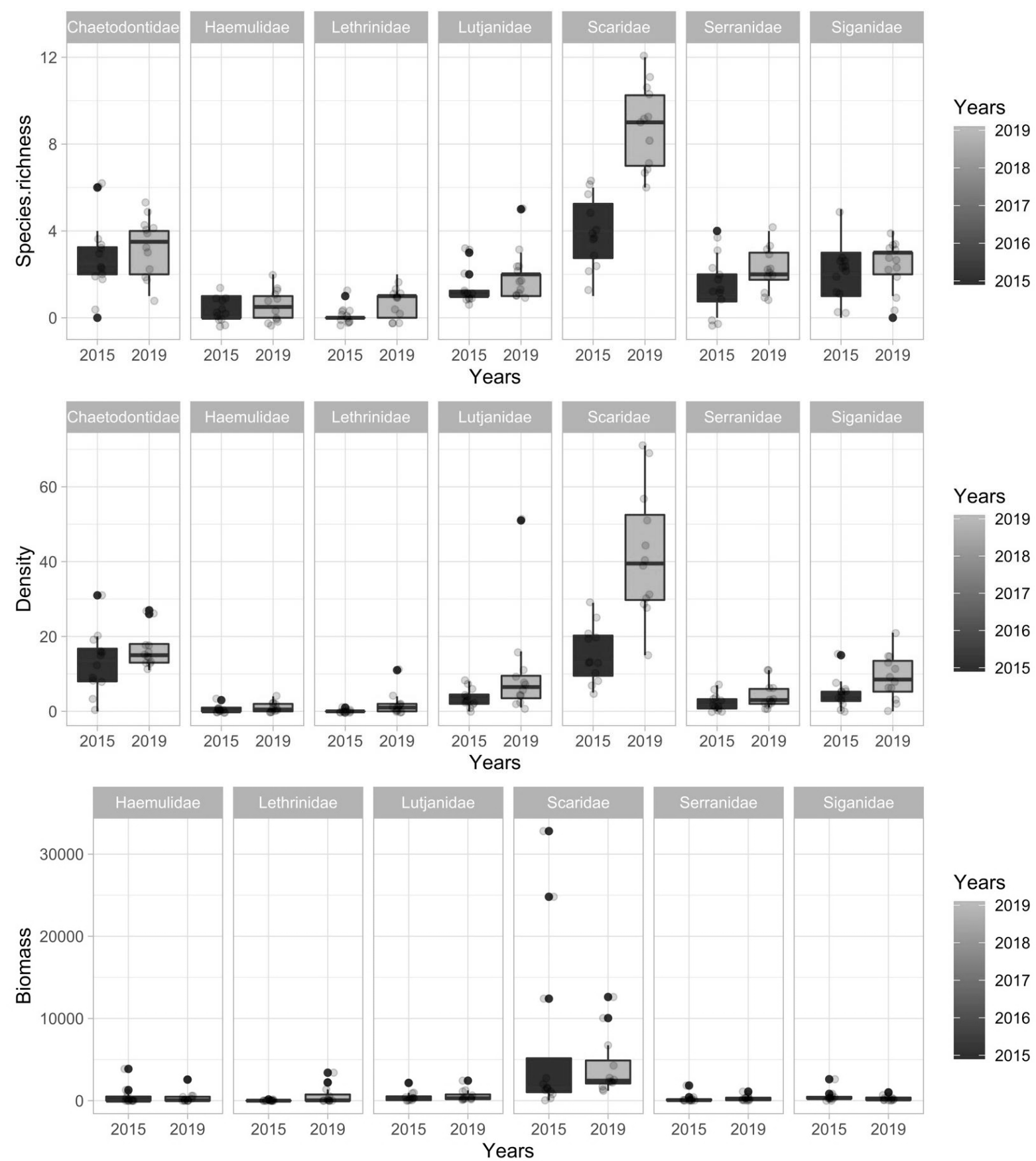

Figure 4. Species richness, density and the biomass of the seven (7) important reef fish in 2015 and 2019, MPAs site location Anambas Islands

The study found a significant difference in reef fish composition between different periods of reef fish monitoring (Approx.-F=3.99, $P=\quad$ 0.05). Different composition of reef fish was relevant in the differentiation between periods highlight of reef fish density $(\mathrm{F}=12.79, P=0.05)$ and also species richness $(\mathrm{F}=9.28, P=$ 0.05 ) (Table 3). The protection status of the MPAs area had a strong effect on the increasing density and species richness. The experimental data showed functional group herbivorous give significance increasing species and density of reef fish composition. Despite the significant differences from density and species richness between different periods studies, the size structure of reef fish between 2015 and 2019 did not change significantly with the result that there was no statical significance reef fish biomass interaction between different periods of studies $($ Fvalue $=0.32222$, Pvalue $=0.5711)$.

To understand the effectiveness of MPAs with their impacts on economically important reef fish, we compared several ecological diversity indices for reef fish in the 2015 and 2019 periods. It has been shown that coral reef ecosystems MPAs were more diverse. Shannon-Wiener 
(H') diversity index MPAs Anambas Islands was based on evaluation periods (mean $\pm \mathrm{SE}$ ): $2015=2.106 \pm 0.4022$ and $2019=2.507 \pm 0.2854$. While for uniformity index from Evenness $(\mathrm{J}): 2015=0.871 \pm 0.049$ and $2019=0.863$ \pm 0.066 , Alpha-fisher index (alpha): $2015=6.082 \pm 2.726$ and $2019=8.610 \pm 2.129$. Effective Number Species (ENS) index: $2015=8.743 \pm 2.841$ and $2019=13.557 \pm$ 3.797. Simpson's dominance index shows that the value was higher in 2015 with S: $2015=0.169 \pm 0.091$ and 2019 $=0.111 \pm 0.039$.

Most MPAs are a management tool that restricts activities proposed to protect resources and habitats from destructive practices (Cortés-Useche et al. 2014). Our result showed positive reef fish community structure (species richness, density, biomass) in the MPAs sites location Anambas Islands. Species richness for three functional groups of reef fish (corallivore, herbivore, and carnivorous) was higher after management controlling in MPAs sites location (2019). A similar condition also occurs to density composition from three functional groups of reef fish that showed an improvement. There was also significant variation in periods of change in fish diversity and density among herbivore groups. This found that the good management of MPAs can improve the reef fish communities and produces higher fish density (Mosquera et al. 2000; Halpern and Warner 2002; Paddack et al. 2009; Muallil et al. 2015). We found a surprising result that increasing diversity and density did not cause a significant rise in reef fish biomass, even the functional groups of herbivorous fish have reduced the mean value of biomass. These results differed with a few studies reef fish studies in several MPA locations. Corrales et al. (2015) found that MPAs influence increasing biomass, in which functional groups of carnivores and herbivores are higher in MPA areas (Beita-Jiménez et al. 2019). Our results indicated that the value of biomass did not change significantly because reef fish populations observed in 2019 have a smaller size than the 2015 period having, reef fish populations have a larger mean size. Increased diversity and density of reef fish due to changes in better control and management of coral reef ecosystems, with restricting fishing activities giving a result that the habitat complexity and water condition were better (McClanahan and Jadot 2017).

The result of fishing pressure on reef fish was additionally detected in shifting in size structure for many functional groups of reef fish, regardless of trophic level differences (Floeter et al. 2006). Overfishing can cause low reef fish biomass, while destructive fishing can eliminate diversity and reduce the large density of reef fish (Neil et al. 2018). This happened in the Anambas Islands, where before 2015, bombing and potassium fishing activities were still rife in Anambas Islands. Changes in the significant increase in diversity and density of reef fish in the MPAs Anambas Island from 2015 to 2019 showed a declining trend of destructive fishing activities, and its frequency has exceedingly reduced. The right decision in managing MPA areas is to restrict fishing areas so that ecosystems that previously were damaged by fishing activities could be recovered. Another decision could be performed to preserve coral reef ecosystems and maintain the composition of reef fish by implementing environmentallyfriendly traditional fisheries. It seems that traditional fishing practices could support maintain a balanced composition of reef fish. Illegal fishing and destructive fishing practice using bombing and potassium could reduce fish diversity, density, and biomass. In almost all areas where MPAs were established, illegal and destructive fishing practices have been reduced (Muallil et al. 2015).

Table 3. MANOVA analysis for community composition for 12 twelves of MPA study sites with the response to different period analysis (2015 and 2019)

\begin{tabular}{|c|c|c|c|c|c|c|}
\hline $\begin{array}{l}\text { Years } \\
\text { Residuals }\end{array}$ & $\begin{array}{c}\text { Df } \\
1 \\
166\end{array}$ & $\begin{array}{c}\text { Pillai } \\
0 . .12969\end{array}$ & $\begin{array}{c}\text { Approx F } \\
\mathbf{3 . 9 9 8 7}\end{array}$ & $\underset{6}{\text { Num Df }}$ & $\begin{array}{c}\text { Den Df } \\
161\end{array}$ & $\begin{array}{c}\operatorname{Pr}(>\mathbf{F}) \\
0.0009272\end{array}$ \\
\hline \multicolumn{7}{|c|}{ 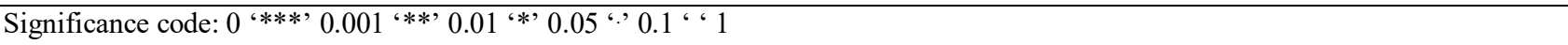 } \\
\hline \multicolumn{7}{|c|}{ Years (2015 and 2019) response density } \\
\hline & Df & Sum Sq & Mean $\mathrm{Sq}$ & F value & $\mathrm{P}(>\mathrm{F})$ & \\
\hline Years & 1 & $1940.7^{1}$ & 1940.72 & 12.792 & 0.001 & $* * *$ \\
\hline Residuals & 166 & 25184.2 & 151.71 & & & \\
\hline \multicolumn{7}{|c|}{ Years (2015 and 2019) response species richness } \\
\hline & Df & Sum Sq & Mean Sq & F value & $\mathrm{P}(>\mathrm{F})$ & \\
\hline Years & 1 & 51.48 & 52.482 & 9.2854 & 0.003 & $* *$ \\
\hline Residuals & 166 & 920.37 & 5.544 & & & \\
\hline \multicolumn{7}{|c|}{ Years (2015 and 2019) response biomass } \\
\hline & Df & Sum Sq & Mean Sq & F value & $\mathrm{P}(>\mathrm{F})$ & \\
\hline Years & 1 & 4087309 & 4087309 & 0.3222 & 0.571 & \\
\hline Residuals & 166 & 2105864345 & 12685930 & & & \\
\hline
\end{tabular}

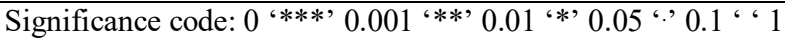



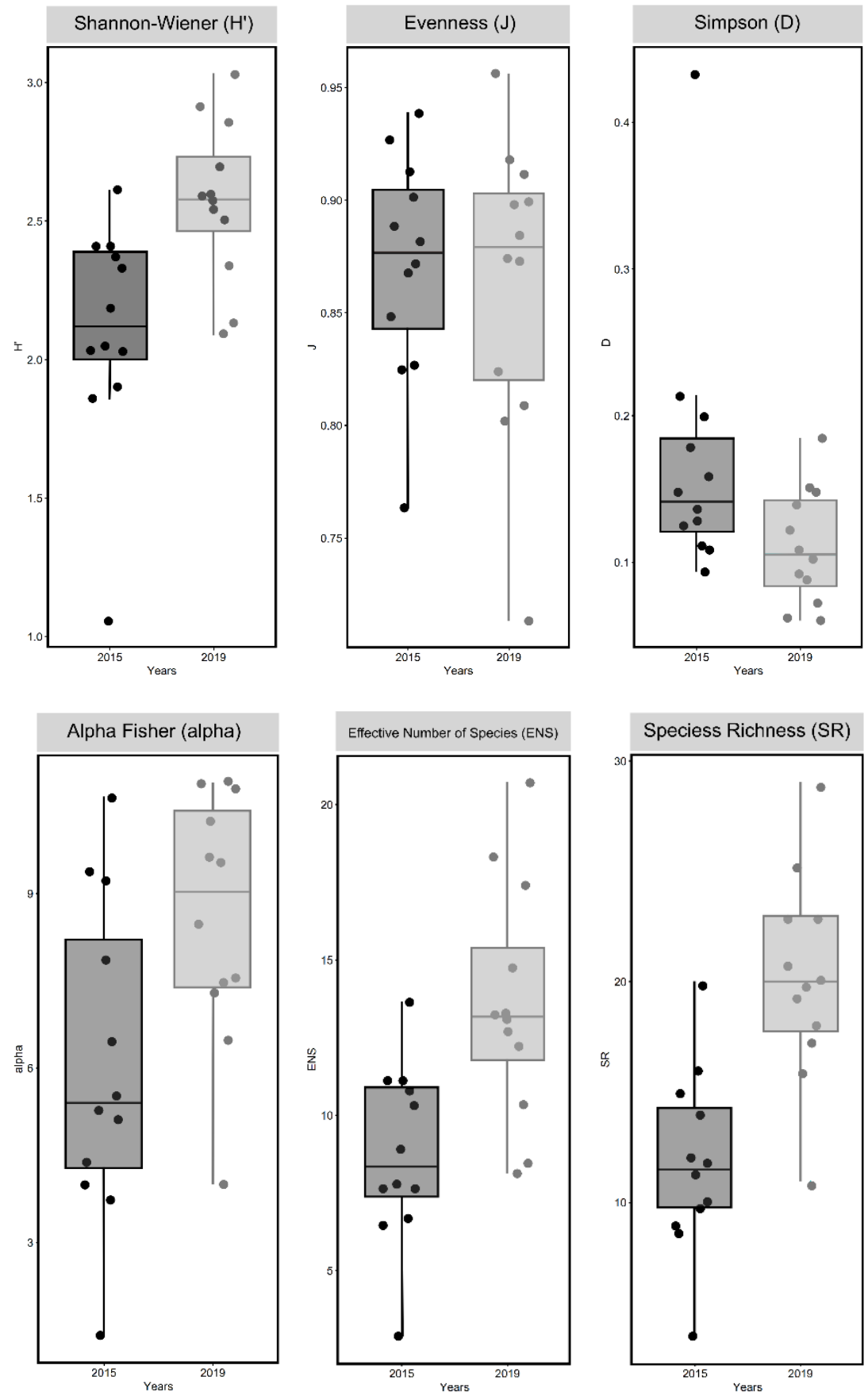

Figure 5. Ecological indices of Coral Reef Fish Anambas Islands, Riau Islands Province, Indonesia in 2015 and 2019

Management of new areas designated as MPAs will require an extended period to convince the succession in the MPAs area. Adaptation from unprotected areas to wellprotected areas will require intense regional control and a persuasive approach to local fishers and communities to comply and understand the importance of MPAs in ecosystem sustainability.

Our results showed that the increase in biomass could not change significantly in areas that have just been given MPA protection, and in accordance with research from (Maliao et al. 2009), the density and biomass of economically important fish are generally higher in MPA areas but not always significant to increase the density and biomass of economically important fish with increasing years of protection of MPA areas. However, intensive management and control in the MPAs Anambas Island have sufficient influence and development, especially for increasing economically important reef fish composition. The impact of intensive control in the MPA region in 2015 to 2019 on Anambas island generated an increase in fish diversity by 2.44 times, fish density increased to 2.57 times, but biomass only increased 1.79 times. Based on studies from (Edgar et al. 2014) the well-managed protected areas have been found to contain more than 5 times the total large of economically important fish biomass. 


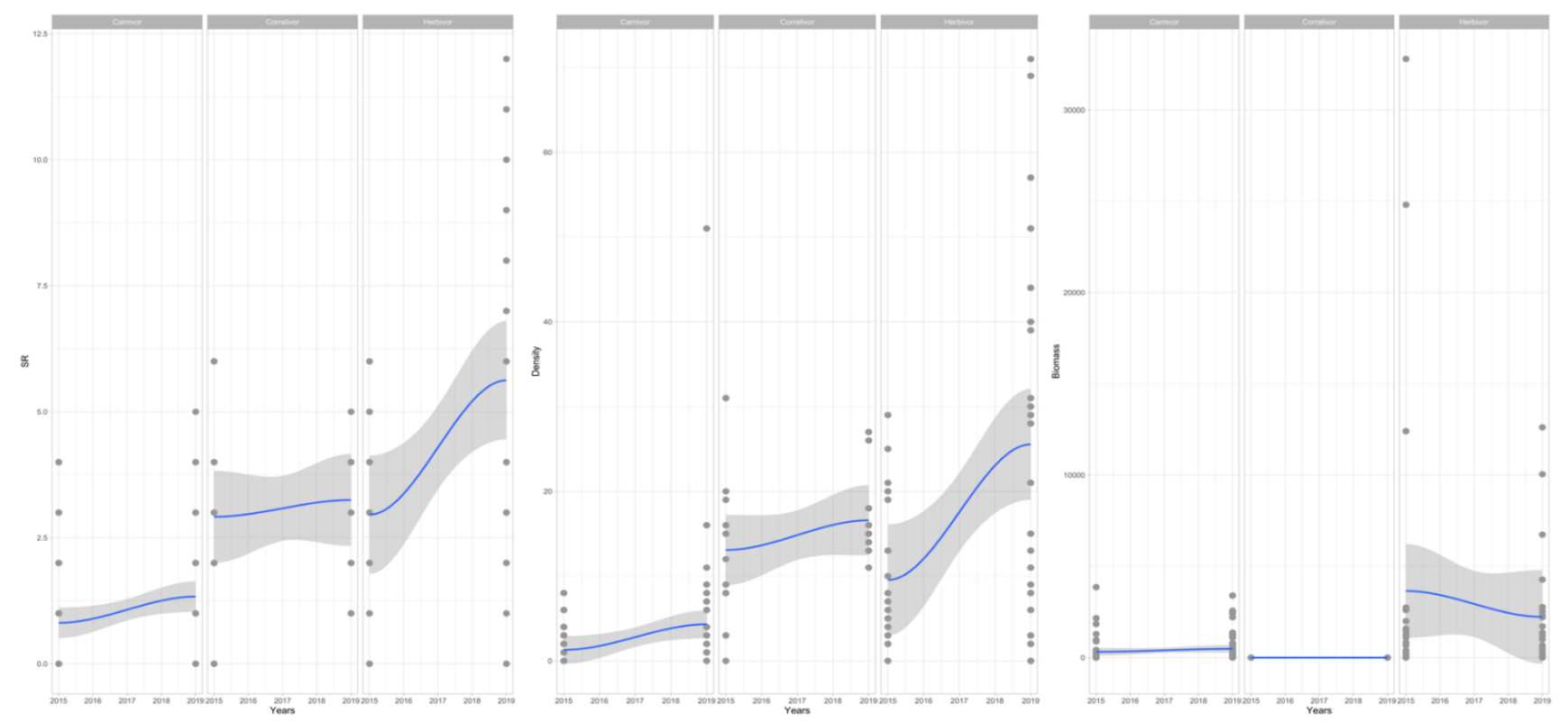

Figure 6. The changing of reef fish composition (SR, density, and biomass) each functional group (corallivore, herbivore, and a carnivore) in 2015 and 2019

From increasing the composition of economically important fish in Anambas from 2015 to 2019, it was found that MPAs might have a positive impact on the condition of an individual or collective reefs because MPAs can influence to have a higher percentage of live coral cover and provide better health indicators (Cortés-Useche et al. 2019). Our findings indicate that local coral management must continue because the benefits of MPAs can increase with efficient management (Beita-Jiménez et al. 2019). We accept and agree with the research from Beita-Jiménez et al. (2019) that the protective benefits, such as MPA are not enough to maintain healthy and productive fish populations, but the point is to protect the coral reef ecosystem to sustainable. In terms of MPA management. The achievement of MPAs was recognized from better coral reef ecosystems, where live coral cover is higher in MPAs than in non-MPAs locations and reduces dead coral algae cover (Cortés-Useche et al. 2019).

The relationship between the percentage of benthic community structure and economically important fish composition of each functional group can be interpreted from Correspondence Analysis (CA) analysis. CA showed the achievement of maps to explain more than $70 \%$ of variables benthic community structure and reef fish community since fish abundance correlates significantly with proportion of benthic community structure including hard coral cover (Komyakova et al. 2013; Peck et al. 2021). The result from CA analysis in 2015 showed that corallivore fish composition (Dens and SR, Figure 7) was more strongly associated with Hard-Coral (HC) and Dead
Coral with Algae (DCA) than herbivore fish and carnivorous fish community composition (Dens and SR). Meanwhile, herbivorous fish biomass had a negative association, and low carnivorous fish had a low correlation with HC and DCA. The surprising result was showed in 2019 that almost these variables had a similar shape correlation with 2015. Although there is an increase in the composition of the density and SR for economically important fish, the relationship between the composition of reef fish and benthic community structure shown by CA analysis had similar in common between the 2015 and 2019 periods. Our research shows that coral reef ecosystems may not have changed in better conditions instead, a decrease may have occurred in the percentage of live coral cover and thus an increase in the percentage of dead coral algae. Based on the analysis, although there was already protection and control of the MPAs area, there are other factors that provide significant factors for decreasing percentage of coral cover, including natural accidence (i.e. thermal stress, ENSO, etc.) and human impact (such as deficient coastal management) (Bellwood et al. 2004; Beita-Jiménez et al. 2019). Information collected in our studies in 2016 showed that coral bleaching events had occurred in several locations in Riau Islands (Wouthuyzen et al. 2018; Abrar et al. 2019; Putra et al. 2019). The coral reefs' decline in the MPAs area Anambas Island was affected by the phenomenon of coral bleaching. This phenomenon could have a significant impact on coral reef mortality (Yahya et al. 2011). 

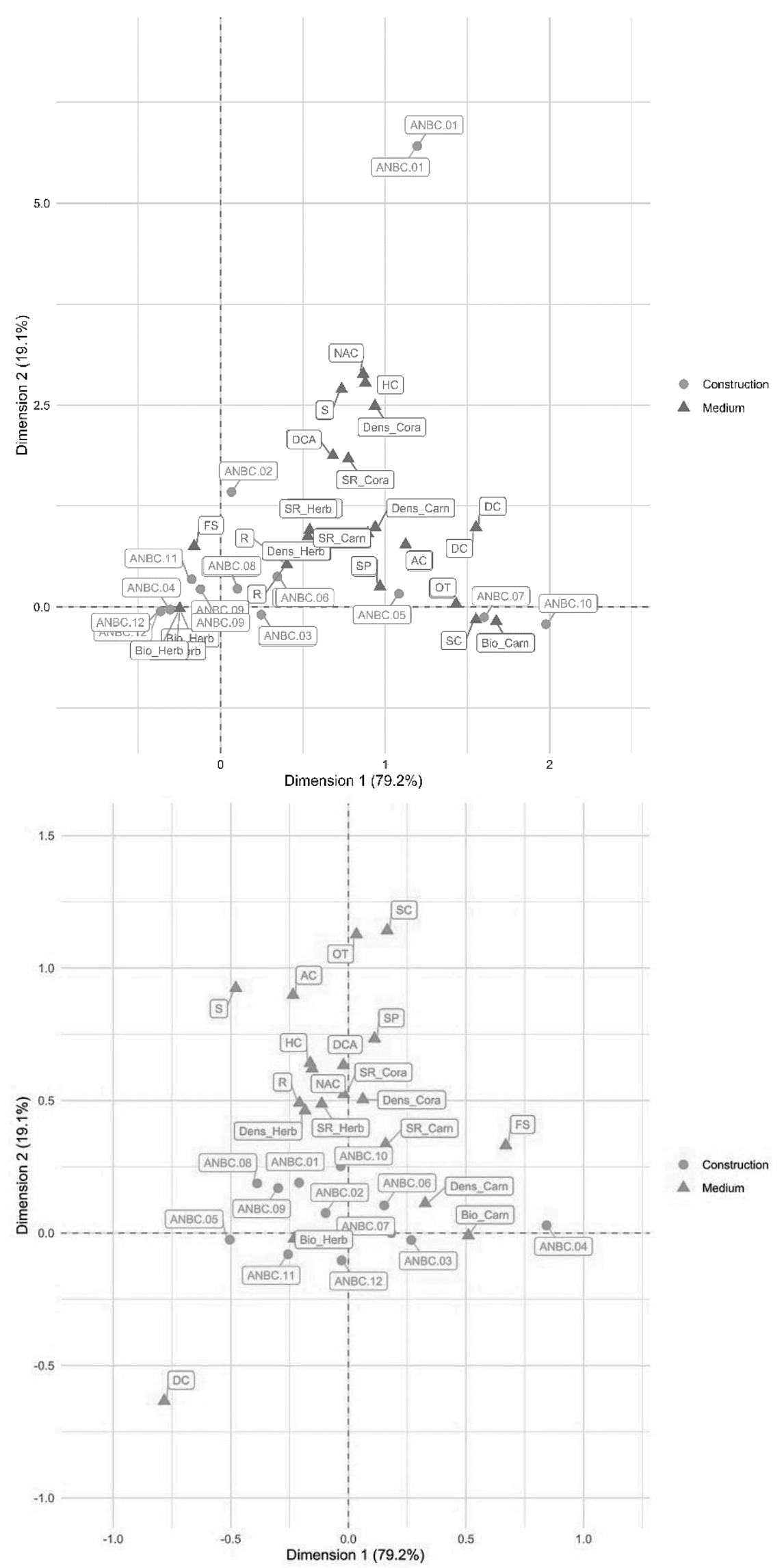

Figure 7. Correspondence analysis (CA) showing the spatial repartition of benthic community structure (HC, DC, DCA, FS, OT, R, S, AC, NAC) and reef fish composition each functional group in 2015 and 2019. The functional group and composition of reef fish were coded by the abbreviation (Cora: Corallivore; Herb: Herbivore; Carn: Carnivore; SR: Species Richness; Dens: Density; Bio: Biomass) 
This study presented the changing benthic community structure and reef fish composition based on different periods (2015 and 2019) in twelve MPAs locations of the Anambas Islands. Live Coral (LC) showed a decreasing percentage of coral cover, while DCA presents increasing coral cover. Reef fish composition (diversity, density, and biomass) from the different functional groups of economically important reef fish in the Anambas Islands showed an increasing trend between study periods. The functional group of herbivorous fish had the most abundant and the most increased density performance. From increasing the composition of economically important fish in Anambas from 2015 to 2019 we found that MPAs might positively impact the condition of reef fish but not on the coral reef ecosystem. Other factors provide significant factors in decreasing the percentage of coral reef ecosystems in Anambas island, including several cases of coral bleaching events hit in Riau Islands in 2016 (Wouthuyzen et al 2018; Abrar et al 2019; Putra et al. 2019).

\section{ACKNOWLEDGEMENTS}

We acknowledge that the funding for this research was provided by Coral Reef Rehabilitation Management Program - Coral Triangle Initiative (COREMAP CTI). In addition, we would like to thank the financial support from Research Centre for Oceanography, Indonesia Institute of Science and Faculty of Marine Science Fisheries, Maritime Raja Ali Haji University. The author would also like to thank Dr. Agung Dhamar Syakti, who always provided invaluable support.

\section{REFERENCES}

Abrar M, Aryono T, Ulumuddin YI, Giyanto. 2019. Long-term monitoring of coral reef condition at Abang Islands and around area, Batam Islands, Kepulauan Riau, Indonesia. AIP Conf Proc 2120: 040016. DOI: 10.1063/1.5115654

Allen GR, Steene R, Humann P, Deloach N. 2003. Reef Fish Identification Tropical Pacific (First). New World Publicatons Inc California

Bacheler NM, Geraldi NR, Burton ML, Muñoz RC, Kellison GT. 2017 Comparing relative abundance, lengths, and habitat of temperate reef fishes using simultaneous underwater visual census, video, and trap sampling. Mar Ecol Prog Ser 574: 141-155. DOI: $10.3354 /$ meps 12172

Beita-Jiménez A, Alvarado JJ, Mena S, Guzmán-Mora AG. 2019. Benefits of protection on reef fish assemblages in a human impacted region in Costa Rica. Ocean Coast Manag 169: 165-170. DOI: 10.1016/j.ocecoaman.2018.12.023

Bellwood DR, Hughes TP, Folke C, Nyström M. 2004. Confronting the coral reef crisis. Nature 429: 827-833. DOI: 10.1038/nature02691

Caldwell ZR, Zgliczynski BJ, Williams GJ, Sandin SA. 2016. Reef fish survey techniques: Assessing the potential for standardizing $\begin{array}{llllll}\text { methodologies. Plos One } 11 & \text { (4): 1-14. DOI: }\end{array}$ 10.1371/journal.pone.0153066

Corrales CM, Delan GG, Rica RLV, Piquero AS, Monte IA. 2015. A Baseline study on coral reef fishes in the marine protected areas in Southern Cebu, Philippines. Trop Technol J 19 (1): 1-8. DOI: 10.7603/s40934-015-0004-2

Cortés-useche C, Muñiz-castillo AI, Calle-triviño J, Yathiraj R, Ariasgonzález JE. 2019. Reef condition and protection of coral diversity and evolutionary history in the marine protected areas of Southeastern Dominican Republic. Reg Stud Mar Sci 32: 100893. DOI: 10.1016/j.rsma.2019.100893

Cox C, Valdivia A, McField M, Castillo K, Bruno JF. 2017. Establishment of marine protected areas alone does not restore coral reef communities in Belize. Mar Ecol Prog Ser 563: 65-79. DOI: 10.3354/meps11984

Du J, Hu W, Makatipu PC, Peristiwady T, Chen B, Dirhamsyah. 2016. Common Reef Fishes of North Sulawesi, Indonesia. Science Press, Beijing.

Edgar GJ, Stuart-Smith RD, Willis TJ, Kininmonth S, Baker SC, Banks S, Thomson RJ. 2014. Global conservation outcomes depend on marine protected areas with five key features. Nature 506 (7487): 216-220. DOI: 10.1038 /nature13022

Fidler RY, Turingan RG, White AT, Alava MNR. 2017. Reef-wide beneficial shifts in fish population structure following establishment of marine protected areas in Philippine coral reefs. Mar Ecol Prog Ser 570: 187-202. DOI: 10.3354/meps12067

Floeter SR, Halpern BS, Ferreira CEL. 2006. Effects of fishing and protection on Brazilian reef fishes. Biol Conserv 128 (3): 391-402. DOI: 10.1016/j.biocon.2005.10.005

Froese R, Pauly D. 2019. FishBase: Concepts, Design and Data sources. ICLARM, Manila, Philippines.

Giyanto, Manuputty A, Abrar M, Siringoringo R, Suharti S, Wibowo K, Zulfianita D. 2014. Panduan Monitoring Kesehatan Terumbu Karang. http://www.coremap.or.id. [Indonesia]

Giyanto, Mumby P, Dhewani N, Abrar M, Iswari MY. 2017. Indeks Kesehatan Terumbu Karang Indonesia COREMAP-CTI. Pusat Penelitian Oseanografi-LIPI, Jakarta. [Indonesia]

Green SJ, White AT, Christie P, Kilarski S, Meneses ABT, Samonte-tan G, Claussen JD. 2011. Emerging marine protected area networks in the coral triangle: Lessons and way forward. Conserv Soc 9 (3): 173188. DOI: $10.4103 / 0972-4923.86986$

Hadi TA, Sihouka J, Shi X, Budiyanto A, Suharsono. 2018. Change in coral reef benthic communities in the Lembeh Strait and Likupang, North Sulawesi, Indonesia. Acta Oceanologica Sinica 37 (12): 45-54. DOI: $10.1007 / \mathrm{s} 13131-018-1287-0$

Halpern BS, Warner RR. 2002. Marine reserves have rapid and lasting effects. Ecol Lett 5 (3): 361-366. DOI: 10.1046/j.14610248.2002.00326.x

Hill J, Wilkinson C. 2004. Methods for Ecological Monitoring of Coral Reefs - A Resource for Managers. Australian Institute of Marine Science, Australia.

Kohler KE, Gill SM. 2006. Coral Point Count with Excel extensions (CPCe): A visual basic program for the determination of coral and substrate coverage using random point count methodology. Comput Geosci 32 (9): 1259-1269. DOI: 10.1016/j.cageo.2005.11.009

Komyakova V, Munday PL, Jones GP. 2013. Relative importance of coral cover, habitat complexity and diversity in determining the structure of reef fish communities. Plos One 8 (12): e83178. DOI: 10.1371/journal.pone.0083178.

Kuiter RH, Tonozuka T. 2001a. Pictorial Guide to Indonesian Reef Fishes. Part 1. Eels to Snapper (Muraenidae to Lutjanidae). Zoonetics, Australia.

Kuiter RH, Tonozuka T. 2001b. Pictorial Guide to Indonesian Reef Fishes. Part 2. Fusiliers to Dragonets (Caesionidae to Callionymidae) (First). Zoonetics, Australia.

Kuiter RH, Tonozuka T. 2001c. Pictorial Guide to Indonesian Reef Fishes. Part 3. Jawfish to Sunfish (Opistognathidae to Molidae). Zoonetics, Australia.

Maliao RJ, White AT, Maypa AP, Turingan RG. 2009. Trajectories and magnitude of change in coral reef fish populations in Philippine marine reserves: A meta-analysis. Coral Reefs 28 (4): 809-822. DOI: 10.1007/s00338-009-0532-6

Mallet D, Wantiez L, Lemouellic S, Vigliola L, Pelletier D. 2014. Complementarity of rotating video and underwater visual census for assessing species richness, frequency and density of reef fish on coral reef slopes. Plos One 9 (1): 0084344. DOI: 10.1371/journal.pone.0084344

McClanahan TR, Jadot C. 2017. Managing coral reef fish community biomass is a priority for biodiversity conservation in Madagascar. Mar Ecol Prog Ser 580: 169-190. DOI: 10.3354/meps12267 
Mosquera I, Côté IM, Jennings S, Reynolds JD. 2000. Conservation benefits of marine reserves for fish populations. Anim Conserv 3 (4): 321-332. DOI: $10.1017 / \mathrm{S} 1367943000001049$

Muallil RN, Deocadez MR, Martinez RJS, Mamauag SS, Nañola CL, Aliño PM. 2015. Community assemblages of commercially importan coral reef fishes inside and outside marine protected areas in the Philippines. Reg Stud Mar Sci 1 (437): 47-54. DOI: 10.1016/j.rsma.2015.03.004

Neil LS, Leisher C, Mangubhai S, Muljadi A, Tapilatu RF. 2018. Fisher perceptions of threats and fisheries decline in the heart of the Coral Triangle. Ocean Life 2 (2): 41-46. DOI: 10.13057/oceanlife/o020201

Paddack MJ, Reynolds JD, Aguilar C, Appeldoorn RS, Beets J, Burket EW, Côté IM. 2009. Recent region-wide declines in caribbean reef fish abundance. Curr Biol 19 (7): 590-595. DOI: 10.1016/j.cub.2009.02.041

Peck M, Tapilatu RF, Kurniati E, Rosado C. 2021. Rapid coral reef assessment using 3D modelling and acoustics: Acoustic indices correlate to fish abundance, diversity and environmental indicators in West Papua, Indonesia. PeerJ 9: e10761. DOI: 10.7717/peerj.10761

Pet-Soede C, van Densen WLT, Pet JS, Machiels MAM. 2001. Impact of Indonesian coral reef fisheries on fish community structure and the resultant catch composition. Fish Res 51 (1): 35-51. DOI: 10.1016/S0165-7836(00)00236-8

Planes S, Lecchini D, Mellin C, Charton JG, Harmelin-vivien M, Kulbicki M, Galzin R. 2012. Environmental determinants of coral reef fish diversity across several French Polynesian atolls. Comptes Rendus Biologies 335 (6): 417-423. DOI: 10.1016/j.crvi.2012.04.002

Pregiwati LA, Wiryawan B, Satria A. 2015. Fisheries management and management of Island, Indonesia. Intl J Bioflux Soc 8 (6): 1048-1063.

Putra RD, Suryanti A, Kurniawan D, Pratomo A. 2018. Responses of herbivorous fishes on coral reef cover in outer island Indonesia (Study Case: Natuna Island). E3S Web of Conf 47: 04009. DOI: 10.1051/e3sconf/20184704009

Putra RD, Suhana MP, Kurniawan D, Abrar M, Siringoringo RM, Sari NWP, Irawan H, Prayetno E, Apriadi T, Suryanti A. 2019. Detection of reef scale thermal stress with Aqua and Terra MODIS satellite for coral bleaching phenomena. AIP Conf Proc 2094: 020024. DOI: $10.1063 / 1.5097493$

Samoilys MA, Carlos G. 2000. Determining methods of underwater visual census for estimating the abundance of coral reef fishes. Environ Biol Fish 57 (3): 289-304. DOI: 10.1023/A:1007679109359

Siringoringo RM, Tanda L, Abrar M, Adji AS, Arbi UY, Hadi TA, Irawan NA. 2015. Monitoring Kesehatan Terumbu Karang dan Ekosistem Terkait di Kawasan Konservasi Perairan Nasional, Taman Wisata Perairan, Kepulauan Anambas dan Laut Sekitarnya. Lembaga Ilmu Pengetahuan Indonesia, Jakarta. [Indonesia]

Topor ZM, Rasher DB, Duffy JE, Brand SJ. 2019. Marine protected areas enhance coral reef functioning by promoting fish biodiversity. Conserv Lett J Soc Conserv Biol 12 (4): 1-9. DOI: 10.1111/conl.12638

Vo ST, Pernetta JC, Paterson CJ. 2013. Status and trends in coastal habitats of the South China Sea. Ocean Coast Manag 85: 153-163. DOI: 10.1016/j.ocecoaman.2013.02.018

Watson JEM, Dudley N, Segan DB, Hockings M. 2014 The performance and potential of protected areas. Nature 515 (7525): 67-73. DOI: 10.1038/nature13947

Wickham H. 2017. Tidyverse: Easily Install and Load the "Tidyverse". R Package Version 1.2.1. 1-5. https://cran.rproject.org/web/packages/tidyverse/tidyverse.pdf

Wilson SK, Graham NAJ, Holmes TH, Macneil MA, Ryan NM. 2018. Visual versus video methods for estimating reef fish biomass. Ecol Indic 85: 146-152. DOI: 10.1016/j.ecolind.2017.10.038

Wouthuyzen S, Abrar M, Lorwens J. 2018. A comparison between the 2010 and 2016 El-Ninō induced coral bleaching in the Indonesian waters. IOP Conf Ser Earth Environ Sci 118: 012051. DOI: $10.1088 / 1755-1315 / 118 / 1 / 012051$

Yahya SAS, Gullström M, Öhman MC, Jiddawi NS, Andersson MH, Mgaya YD, Lindahl U. 2011. Coral bleaching and habitat effects on colonisation of reef fish assemblages: An experimental study. Estuar Coast Shelf Sci 94 (1): 16-23. DOI: 10.1016/j.ecss.2011.04.012 